Tersedia online di: http://ejournal-balitbang.kkp.go.id/index.php/jra

\title{
INSIDENSI DAN PREVALENSI INFEKSI WHITE SPOT SYNDROME VIRUS PADA PLANKTON DI TAMBAK BUDIDAYA UDANG
}

\author{
Bunga Rante Tampangallo\#, Herlinah, dan Muhammad Chaidir Undu
}

Balai Riset Perikanan Budidaya Air Payau dan Penyuluhan Perikanan

(Naskah diterima: 11 Oktober 2017; Revisi final: 27 Desember 2017; Disetujui publikasi: 27 Desember 2017)

\begin{abstract}
ABSTRAK
Plankton di tambak super-intensif dalam berbagai bentuk seperti mikroalga, rotifer, dan kopepoda seringkali merupakan agen pembawa virus bintik putih atau white spot syndrome virus (WSSV) yang sangat potensial. Penelitian bertujuan untuk mengetahui insidensi dan prevalensi infeksi WSSV pada plankton di tambak budidaya udang vaname, Litopenaeus vannamei, super-intensif di Kabupaten Barru, Sulawesi Selatan. Penelitian ini dilakukan dari bulan Januari sampai dengan Desember 2015. Sampel plankton dikoleksi dari sumber pemasukan air tambak superintensif (inlet), outlet, instalasi pengolahan air limbah tambak yang sedang melakukan kegiatan budidaya. Hasil penelitian ini menunjukkan bahwa insidensi infeksi WSSV terjadi di bulan Januari, Oktober, dan November. Pada bulan Januari, plankton yang terdeteksi mengalami infeksi WSSV adalah dari petakan tambak P1, outlet-1, outlet dan inlet tambak-3, serta inlet hatchery. Selanjutnya pada bulan Oktober, plankton yang terinfeksi WSSV adalah dari petakan tambak P2, P7, P8, dan IPAL. Pada bulan November, WSSV hanya terdeteksi pada plankton di inlet petakan tambak P3 dan inlet hatchery. Prevalensi WSSV tertinggi diperoleh pada plankton di bulan November $(66,67 \%)$; bulan Januari $(62,5 \%$; dan Oktober $(40,00 \%$. Plankton dalam petakan tambak cenderung lebih sensitif terhadap infeksi WSSV sehingga berpotensi sebagai vektor dalam tambak pembesaran udang.
\end{abstract}

KATA KUNCl: insidensi; prevalensi; WSSV; plankton; budidaya super-intensif

ABSTRACT: Incidence and prevalence of white spot syndrome virus infection on plankton in super intensive shrimp culture pond. By: Bunga Rante Tampangallo, Herlinah, and Muhammad Chaidir Undu

\begin{abstract}
Plankton, found as microalgae, rotifer, and copepods, in super intensive ponds are potential disease agents of white spot syndrome virus (WSSV). This study aims to evaluate the incidence and prevalence of WSSV on plankton in super intensive Litopenaeus vannamei shrimp ponds in Barru Regency, South Sulawesi. The study was conducted for one year from January to December 2015. Plankton were collected from the inlets, outlets, and waste water management plant of the super intensive ponds which were running of culturing shrimps. The results showed that the incidences of WSSV infection on plankton were occurred in January, October, and November of 2015. The detected plankton with WSSV infection occurred in January and were collected from pond PI, outlet-I, outlets and inlets of pond-3 as well as the inlets of the hatchery. In October, the identified plankton infected with W SSV were collected from ponds P2, P7, P8, and their waste water management plant. In November, W SSV was only detected on plankton found in the inlets of pond-3 and the inlets of the hatchery. The highest WSSV prevalence was obtained on plankton isolated in November $(66.67 \%)$ followed by plankton isolated in January $(62.5 \%$, and in October $(40 \%)$. The study found that plankton in pond tend to be more sensitive to WSSV infection which could potentially serve as WW SV vectors in shrimp culture.
\end{abstract}

KEYWORDS: ～incidence; prevalence; WSSV; plankton; supra-intensive shrimp farm

\section{PENDAHULUAN}

Produksi udang hasil budidaya di Indonesia saat ini telah mengalami peningkatan yang cukup signifikan dan telah menduduki posisi teratas sebagai importir

\footnotetext{
\# Korespondensi: Balai Riset Perikanan Budidaya Air Payau dan Penyuluhan Perikanan. Jl. Makmur Dg. Sitakka No. 129, Maros 90512, Sulawesi Selatan, Indonesia.

Tel. + 62411371544

E-mail: bungatampangallo@yahoo.com
}

udang ke Amerika dan Jepang (Trobos, 2016). Hal ini didukung oleh adanya udang introduksi (vaname) yang telah masuk ke Indonesia dan metode budidayanya telah dikuasai oleh pembudidaya. Perkembangan usaha budidaya udang vaname ini juga telah mengarah ke sistem industri, misalnya, sebagian besar pembudidaya telah melakukan budidaya intensif hingga superintensif. Adanya sistem budidaya dengan kepadatan yang cukup tinggi ini (bisa lebih dari $1.000 \mathrm{ekor} / \mathrm{m}^{2}$ ) dapat menyebabkan jarak antara inang dan patogen 
semakin dekat sehingga rawan terserang penyakit, seperti white spot syndrome virus (WSSV).

WSSV merupakan virus double-stranded deoxyrinonucleic acid (dsDNA) yang bersifat sangat virulen pada budidaya udang, termasuk udang vaname. Virus ini berukuran panjang 210-420 nm, diameter 70-167 nm, dan memiliki multi-filamen menyerupai sebuah ekor pada salah satu ujung virionnya (SanchezPaz, 2010). Infeksi virus ini pada budidaya udang penaeid dapat menyebabkan kematian massal hingga 100\% dalam 3-10 hari setelah terdeteksi mengalami infeksi (Xu et al., 2006). Infeksi virus ini telah menyebabkan penurunan produksi udang windu di Indonesia sejak tahun 1995 sehingga perlu dipantau keberadaannya agar tidak menyebabkan kerugian bagi industri budidaya udang. WSSV dapat menular melalui air dari tambak udang yang melakukan panen lebih awal oleh karena terserang WSSV dan membuang air tambak ke saluran tanpa treatment terlebih dahulu. Demikian pula adanya penggantian air secara rutin tanpa memperhatikan aktivitas yang dilakukan oleh tambak di sekitarnya, sehingga akan memperbesar peluang penularan virus tersebut. Hal ini disebabkan oleh karena saluran pemasukan dan pembuangan digunakan secara bersamaan. Esparza et al. (2009) melaporkan bahwa air dari tambak yang positif terdeteksi mengalami infeksi WSSV dapat menginduksi terjadinya infeksi WSSV.

Penyebaran virus WSSV menjadi sangat mudah oleh karena beberapa organisme air telah dilaporkan dapat menjadi pembawa virus ini seperti kepiting dan ikan liar dalam saluran air/tambak (Tompo et al., 2013), serangga rawa-rawa pantai (Chironomid spp.) dan beberapa jenis moluska (Soetrisno, 2004), kepiting laut (Otta et al., 1999), sedimen tambak (Nurhidayah, 2013) bahkan beberapa jenis plankton (Zhang et al., 2006; 2008; dan Liu et al., 2007). Demikian pula plankton dalam berbagai bentuk seperti mikroalga, rotifer, dan kopepoda merupakan agen pembawa infeksi virus bintik putih atau white spot syndrome virus (WSSV) yang sangat potensial (Esparza-Lea et al., 2009). Berdasarkan hal tersebut di atas maka tujuan penelitian ini adalah melakukan inventarisasi terhadap insidensi dan prevalensi infeksi WSSV pada plankton di tambak budidaya udang vaname super-intensif agar kejadian infeksi dapat ditelusuri sehingga tidak menimbulkan kerugian yang lebih besar di kalangan pembudidaya.

\section{BAHAN DAN METODE}

\section{Lokasi Penelitian}

Penelitian dilakukan dengan mengacu pada metode survai terhadap tambak yang melakukan kegiatan budidaya udang vaname super-intensif di Kabupaten Barru. Berdasarkan hasil survai lokasi, diketahui bahwa tambak yang melakukan budidaya udang vaname super-intensif di Kabupaten Barru terletak di dua kecamatan. Oleh karena itu, survai dilakukan dengan mengambil sampel plankton pada titik sampling/survai seperti pada Tabel 1.

Posisi masing-masing lokasi tambak budidaya super-intensif dapat dilihat pada Gambar 1. Setiap petak tambak memiliki saluran pemasukan dan pengeluaran sedangkan untuk instalasi pengolahan air limbah (IPAL) hanya terdapat pada tambak yang berlokasi di Dusun Lajange, dan tak satu pun dari ketiga lokasi survai tersebut yang menggunakan tandon air bersih.

\section{Sampling Plankton}

Pengambilan sampel plankton air pada tambak yang melakukan kegiatan budidaya dilakukan dua kali sebulan. Penelitian dilakukan selama satu tahun. Teknik pengambilan sampel ditentukan secara proporsional, terkait luasan petak tambak dan instalasi pendukung tambak yang digunakan. Pada petak tambak P1, P2, dan P4, sampel air diambil pada empat titik sudut petakan per tambak, masing-masing 25 liter, Ialu disaring dengan menggunakan plankton net. Pada titik sampling P3, P5, P6, P7, dan P8, masing-masing 34 liter sampel air tambak diambil dari tiga titik lalu disaring menjadi satu sampel per tambak. Sampel air inlet diambil dari laut tempat memompa air masuk, sedangkan air sampel dari outlet diambil di saluran pintu pembuangan tambak. Sampel plankton diambil dengan cara menyaring air laut/tambak/inlet/outlet/IPAL masingmasing sebanyak 100 liter dengan menggunakan plankton net (ukuran $25 \mu \mathrm{m}$ ). Air yang tersaring ditampung dalam botol $(100 \mathrm{~mL}$ ) kemudian diambil $2 \mathrm{~mL}$ selanjutnya dimasukkan ke dalam mikrotube steril untuk dianalisis WSSV dan selebihnya dimasukkan ke dalam botol sampel yang diberi larutan lugol (1\% untuk identifikasi keanekaragaman jenis plankton.

\section{Identifikasi Plankton}

Identifikasi plankton dilakukan dengan terlebih dahulu mengocok sampel air agar homogen. Sampel kemudian diambil sebanyak $1 \mathrm{~mL}$ lalu diteteskan di atas Sedgwick Rafter Counter Cell (SRC) dan diamati di bawah mikroskop cahaya dengan pembesaran 10x. Pengamatan dilakukan pada 100 kotak SRC. Identifikasi jenis sampai tingkat genus mengacu pada pustaka Newell \& Newell (1977), Yamaji (1976), dan Botes (2003).

\section{Deteksi WSSV}

Deteksi WSSV dilakukan melalui beberapa tahap, yakni ekstraksi DNA dan amplifikasi PCR menggunakan 
Tabel 1. Titik pengambilan sampel plankton di tambak budidaya udang vaname super-intensif di Kabupaten Barru, Sulawesi Selatan

Table 1. Plankton sampling points in shrimp pond area in Barru Regency, South Sulawesi

\begin{tabular}{|c|c|c|c|}
\hline $\begin{array}{l}\text { Kecamatan } \\
\text { District }\end{array}$ & $\begin{array}{l}\text { Kelurahan/desa } \\
\text { Village }\end{array}$ & $\begin{array}{l}\text { Kode tambak } \\
\text { Pond code }\end{array}$ & $\begin{array}{l}\text { Kode prasarana tam bak } \\
\text { Pond facility code }\end{array}$ \\
\hline Soppeng Riaja & Lawallu & P3 & $\begin{array}{c}\text { Inlet -3 (I3) } \\
\text { Outlet -3 }(\mathrm{O} 3) \\
\text { Inlet hatchery (IH) }\end{array}$ \\
\hline \multirow[t]{2}{*}{ Mallusetasi } & Jalange & $\begin{array}{l}\text { P1 } \\
\text { P2 } \\
\text { P4 } \\
\text { P7 } \\
\text { P8 }\end{array}$ & $\begin{array}{l}\text { Inlet -1 (I1) } \\
\text { Outlet -1 (01) } \\
\text { IPAL }\end{array}$ \\
\hline & Kupa & $\begin{array}{l}\text { P5 } \\
\text { P6 }\end{array}$ & $\begin{array}{c}\text { Inlet -5 (I5) } \\
\text { Outlet -5 (05) } \\
\text { Outlet -6 (06) }\end{array}$ \\
\hline
\end{tabular}

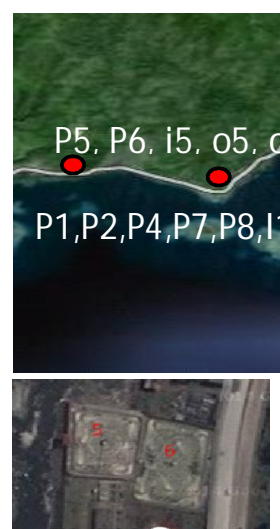

(A)

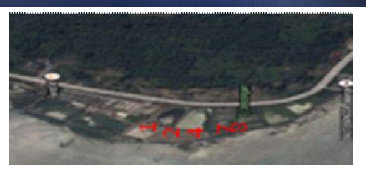

(B)

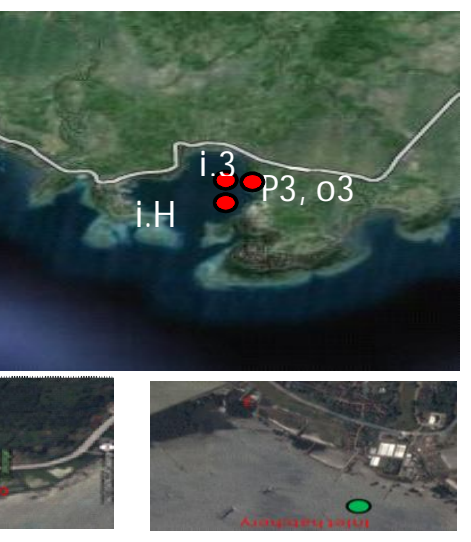

(C)

Gambar 1. Lokasi pengambilan sampel plankton air tambak budidaya udang di Kabupaten Barru, Sulawesi Selatan ( $i=$ inlet; $0=$ outlet); (A) tambak di Desa Kupa, (B) tambak di Desa Jalange, dan (C) tambak di Desa Lawallu.

Figure 1. Sampling locations of plankton at shrimp pond center in Barru Regency of South Sulawesi ( $\mathrm{i}=$ inlet; $0=$ outlet) (A) shrimp pond in Kupa Village, $(B)$ shrimp pond in Jalange Village, and (C) shrimp pond in Lawallu Village.

kit IQ2000, elektroforesis, serta dokumentasi. Ekstraksi DNA WSSV sampel plankton air tambak super-intensif dimulai dengan melakukan sentrifugasi menggunakan sentrifuge (Effendorf tipe 5415D) dengan kecepatan 12.000 rpm selama 15 menit. Supernatan dibuang dan pelet plankton yang terbentuk kemudian ditambahkan dengan yeast tRNA sebanyak $10 \mu \mathrm{L}$ dan ddH2O sebanyak $290 \mu \mathrm{L}$. Proses ekstraksi DNA WSSV selanjutnya mengikuti manual IQ2000 menggunakan metode CTAB-dTAB (Oie, 2013). Pelet
DNA yang telah kering dilarutkan dalam $10 \mu \mathrm{L}$ TE buffer lalu disimpan dalam frezer $-20^{\circ} \mathrm{C}$ untuk analisis lebih lanjut.

Amplifikasi DNA WSSV dilakukan dengan mengacu pada prosedur kit IQ2000 (Oie, 2013) dan menggunakan PCR (GeneAmp PCR system 2700). Hasil PCR dielektroforesis (compact M biometra PS304) pada agarose $2 \%$ dalam $1 \times$ TBE buffer dan ditambahkan gelred (1\%/) sebagai pewarna. Pita DNA didokumentasi menggunakan gel dokumentasi UVstar 312 Biometra. 
Analisis pita DNA dilakukan dengan mengacu pada pita DNA kontrol positif dan marker DNA mengikuti manual kit IQ2000.

\section{Analisis Data}

Pada penelitian ini, insidensi diartikan sebagai frekuensi ditemukannya sampel plankton yang positif terinfeksi WSSV selama penelitian. Prevalensi adalah perbandingan antara jumlah sampel yang positif dibagi jumlah sampel yang diamati. Data disajikan dalam bentuk tabel.

\section{HASIL DAN BAHASAN}

\section{Insidensi WSSV}

Budidaya tambak super-intensif merupakan usaha industrial; oleh karena itu, pemantauan terhadap kondisi air budidaya sangat perlu diperhatikan termasuk kondisi plankton dalam petakan, inlet/sumber air maupun air buangannya. Hasil penelitian ini menunjukkan bahwa insidensi WSSV positif pada sampel plankton dalam air tambak budidaya udang vaname super-intensif didapatkan pada bulan Januari, Oktober, dan November 2015. Gambaran hasil deteksi WSSV terhadap plankton yang ada dalam perairan sentra budidaya udang vaname supra-intensif di Kabupaten Barru dapat dilihat pada Gambar 2.

Pada bulan Januari, WSSV positif terdapat pada plankton dalam petakan tambak P1, inlet, dan outlet-3, serta inlet hatchery. Hal ini kemungkinan disebabkan oleh karena juvenil udang vaname dalam petakan tambak ini juga telah positif mengalami infeksi WSSV dengan prevalensi 100\% (Tampangallo et al., 2016). Pada inlet-3, outlet-3, dan inlet hatchery, plankton telah terpapar oleh padatnya kegiatan budidaya udang vaname di sekitar lokasi pengambilan sampel dan beberapa tambak telah melakukan panen paksa oleh karena infeksi WSSV. Di sekitar daerah ini terdapat tambak intensif dan semiintensif yang umumnya membuang air pada saluran yang sama dengan outlet-3 dan bermuara ke laut yang juga berfungsi sebagai inlet tambak-3 (I3) dan hatchery (IH).

Insidensi plankton yang positif terdeteksi mengalami infeksi WSSV selanjutnya diperoleh di bulan Oktober dari tambak P2, P7, P8, dan tandon IPAL. Adanya plankton yang positif terdeteksi mengalami infeksi WSSV pada petakan ini disebabkan karena juvenil udang vaname dalam petakan tambak tersebut telah positif mengalami infeksi WSSV, bahkan petak P1 telah dipanen lebih awal karena serangan penyakit. Hal ini menyebabkan hasil positif WSSV pada plankton di IPAL yang merupakan tandon penampungan air buangan tambak P1, P2, P4, P7, dan P8. Pada bulan November, tambak yang masih melakukan kegiatan budidaya hanya pada petak P3 sehingga sampling hanya dilakukan di lokasi tersebut dan hasilnya didapatkan plankton positif terdeteksi mengalami infeksi WSSV pada inlet-13 dan inlet hatchery.

Penularan WSSV melalui air tambak yang terserang WSSV telah dilaporkan oleh Esparza-Lea et al. (2009). Air tambak yang telah terdeteksi mengalami infeksi oleh WSSV walaupun telah disaring dengan saringan

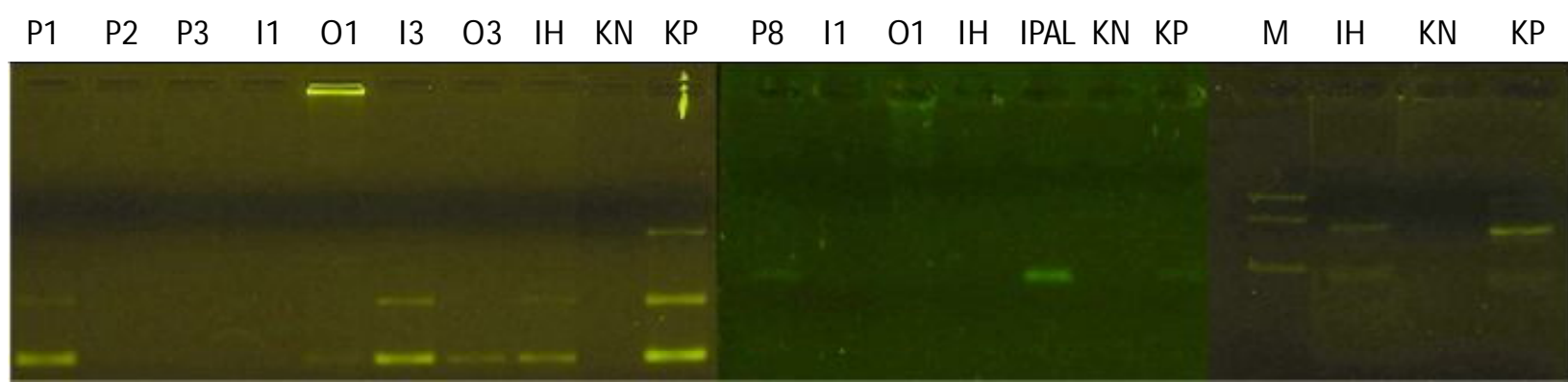

Keterangan: P1-P3= plankton dari petak tambak P1-3 di bulan Januari 2015; I1-IH= plankton dari inlet dan outlet di bulan Januari 2015; P6= plankton dari petak tambak-6 di bulan Oktober 2015, I1 dan 01= plankton dari inlet dan outlet-1 di bulan Oktober 2015; IPAL= sampel plankton dari Instalasi Pengolahan Air Limbah di bulan Oktober 2015. IH= plankton dari inlet hatchery di bulan November 2015; $M=$ marker 848 bp, 630 bp, dan 333 bp; $K N=$ kontrol negatif, $K P=$ kontrol positif. Sampel positif= sumur/kolom ke-1, 5, 6, 7, 8, 11, 15, dan 19

Note: $\quad P 1-P 3=$ plankton form pond $P 1-3$ in January 2015; I1-IH = plankton form inlet and oulet in January 2015; $P 6=$ plankton form pond- 6 in October 2015; II and 01 = plankton from inlet and outlet- 1 in October 2015; IPAL= plankton from wastewater treatment instalation in October 2015; IH= plankton from inlet hatchery in November 2015; $M=$ marker 848 bp, 630 bp, 333 bp; KN= Negative control; $K P=$ positive control. Positive sample= weel/column 1, 5, 6, 7, $8,11,15$, and 19

Gambar 2. Amplifikasi PCR dari sampel plankton yang diisolasi dari beberapa lokasi tambak udang super-intensif.

Figure 2. PCR amplification of plankton samples isolated from several locations of super intensive shrimp ponds. 
mesh size $100 \mu \mathrm{m}$ dan $>0,65 \mu \mathrm{m}$ masih dapat menyebabkan udang positif WSSV. Adanya penggunaan tandon penampungan air limbah tambak diharapkan dapat mengurangi ataupun membunuh partikel virus WSSV sehingga penularannya dapat sedikit dieliminir. Hal ini dapat dilihat pada Tabel 2, bahwa pada umumnya plankton yang positif WSSV dalam petakan tambak tidak didapatkan lagi pada pengamatan selanjutnya. Suhu air $32^{\circ} \mathrm{C}$ selama enam jam dapat menghambat replikasi WSSV dan mengurangi jumlah udang yang mati (Rahman et al., 2007). Selama kegiatan penelitian ini, suhu air dalam petakan tandon $>30^{\circ} \mathrm{C}$ sehingga diharapkan dapat menekan perkembangan virus WSSV. Pada penelitian ini, pengambilan sampel tidak dilanjutkan pada bulan berikutnya setelah diketahui bahwa plankton positif terdeteksi mengalami infeksi WSSV di tandon IPAL.
Seringnya didapatkan plankton yang positif mengalami infeksi WSSV di inlet-3 dan inlet hatchery yang merupakan sumber air untuk kegiatan budidaya di sekitarnya dapat menjadi pertanda bahwa plankton dalam perairan ini dapat menjadi vektor WSSV yang kemungkinan besar karena pengaruh aktivitas budidaya di sepanjang pesisir pantai tersebut. Beberapa jenis mikroalga laut dilaporkan dapat menularkan WSSV secara horisontal (Liu et al., 2007). Cacing Dendronereis spp. di alam juga dilaporkan telah positif WSSV dan virus ini dapat melakukan replikasi virus dalam tubuhnya (Desrina et al., 2012). Telur rotifer (Yan et al., 2004), Brachionus ureus dan kopepoda (Zhang et al., 2006; 2008), bahkan mikroplankton (Esparza-Lea et al., 2009) telah diperoleh positif WSSV dan dapat menjadi carier WSSV. Hal ini sejalan dengan hasil penelitian ini, diketahui bahwa Brachionus sp.

Tabel. 2. Insidensi WSSV pada plankton dalam air tambak udang di Kecamatan Mallusetasi dan Soppeng Riaja, Kabupaten Barru, Sulawesi Selatan

Table 2. WSSV incidence of plankton from shrimp ponds in Mallusetasi and Soppeng Riaja area, Barru Regency of South Sulawesi

\begin{tabular}{|c|c|c|c|c|c|c|c|c|c|c|c|c|}
\hline \multirow{2}{*}{$\begin{array}{c}\text { Titik sampling } \\
\text { The sampling } \\
\text { point }\end{array}$} & \multicolumn{12}{|c|}{ Bulan (2015)/Month (2015) } \\
\hline & $\begin{array}{l}\text { Januari } \\
\text { January }\end{array}$ & $\begin{array}{l}\text { Februari } \\
\text { February }\end{array}$ & $\begin{array}{l}\text { Maret } \\
\text { March }\end{array}$ & $\begin{array}{l}\text { April } \\
\text { April }\end{array}$ & $\begin{array}{l}\text { Mei } \\
\text { May }\end{array}$ & $\begin{array}{l}\text { Juni } \\
\text { June }\end{array}$ & $\begin{array}{l}\text { Juli } \\
\text { July }\end{array}$ & $\begin{array}{l}\text { Agustus } \\
\text { August }\end{array}$ & $\begin{array}{l}\text { September } \\
\text { September }\end{array}$ & $\begin{array}{l}\text { Oktober } \\
\text { October }\end{array}$ & $\begin{array}{l}\text { November } \\
\text { November }\end{array}$ & $\begin{array}{l}\text { Desember } \\
\text { December }\end{array}$ \\
\hline P1 & + & - & - & - & - & - & na & - & - & na & na & na \\
\hline P2 & - & - & - & - & - & - & na & - & - & + & na & na \\
\hline P3 & - & - & - & - & - & - & na & - & $\mathrm{Na}$ & - & - & - \\
\hline P4 & na & - & - & - & - & - & na & na & $\mathrm{Na}$ & - & na & na \\
\hline P5 & na & na & na & - & - & - & na & na & $\mathrm{Na}$ & na & na & na \\
\hline P6 & na & na & na & - & - & - & na & na & $\mathrm{Na}$ & na & na & na \\
\hline P7 & na & na & na & na & na & na & na & na & $\mathrm{Na}$ & + & na & na \\
\hline P8 & na & na & na & na & na & na & na & na & $\mathrm{Na}$ & + & na & na \\
\hline I.1 & - & - & - & - & - & - & na & - & - & - & na & na \\
\hline 0.1 & + & - & - & - & - & - & na & - & - & - & na & na \\
\hline 1.3 & + & - & - & - & - & - & na & - & - & - & + & - \\
\hline 0.3 & + & - & - & - & - & - & na & na & na & na & na & na \\
\hline I.H & + & - & - & - & - & - & - & - & - & - & + & - \\
\hline 1.5 & na & na & na & - & - & - & na & na & na & na & na & na \\
\hline 0.5 & na & na & na & - & - & - & na & na & na & na & na & na \\
\hline 0.6 & na & na & na & - & - & - & na & na & na & na & na & na \\
\hline IPAL & na & - & - & - & - & - & na & na & na & + & na & na \\
\hline $\begin{array}{c}\text { Prevalensi } \\
\text { Prevalence }(\%)\end{array}$ & 63 & 0 & 0 & 0 & 0 & 0 & 0 & 0 & 0 & 40 & 67 & 0 \\
\hline
\end{tabular}

Keterangan: na= tidak ada sampel/tidak dianalisis; $(-)=$ negatif WSSV; $(+)=$ positif WSSV; P1-8= plankton di petak tambak; $I 1=$ plankton inlet tambak-1.;01= plankton outlet tambak-1; $13=$ plankton inlet tambak-3;03= plankton outlet tambak-3; IH= plankton inlet laut hatchery; $15=$ plankton inlet tambak-5; 05= plankton outlet tambak-5;06= plankton outlet tambak 6 ; IPAL= plankton di instalasi pengolahan air limbah (IPAL) tambak 1, 2, 4, 7, 8

Note: $\quad$ na= no sample/not analysed; $(-)=$ negative WSSV; $(+)=$ positive WSSV; $P 1-P 8=$ plankton form pond $1-8 ; \quad I 1=$ plankton from inlet pond- $1 ; 01=$ plankton from pond $1 ; 13=$ plankton from inlet pond-3; $03=$ plankton from outlet pond $-3 ; \mathrm{IH}=$ plankton from inlet hatchery; $\mathrm{I} 5=$ plankton from inlet pond $-5 ; 05=$ plankton from outlet pond $-5 ; 06=$ plankton from outlet pond-6; IPAL= plankton from wastewater instalation in pond $1,2,4,7,8$ 
mendominasi zooplankton yang ada dalam perairan sentra budidaya udang vaname di lokasi penelitian.

\section{Prevalensi}

Berdasarkan data pada Tabel 2, terlihat bahwa prevalensi plankton positif mengalami infeksi WSSV tertinggi terjadi pada bulan November $66,67 \%$ (dua dari tiga sampel plankton yang diamati); disusul pada bulan Januari $62,5 \%$ (empat dari tujuh sampel); dan terendah pada bulan Oktober 40\% (empat dari 10 sampel). Hal ini dapat menjadi acuan dalam kegiatan budidaya udang di sekitar lokasi penelitian, dan pada umumnya plankton yang positif terdeteksi mengalami infeksi WSSV ini terdeteksi di sampel air laut yang merupakan sumber air budidaya. Plankton dapat menjadi vektor yang sangat mudah menularkan virus (Liu et al., 2007).

\section{Jenis dan Kelimpahan Plankton}

Hasil pengamatan terhadap jenis plankton yang ada dalam petakan tambak, inlet, outlet, IPAL, dan laut selama penelitian dapat dilihat pada Tabel 3. Pada Tabel 3 ditampilkan jenis fitoplankton, zooplankton, krustasea, dan cacing dari semua titik pengambilan sampel selama satu tahun pengamatan. Data yang ditampilkan telah di komposit dan dirata-ratakan.

Hasil pengamatan diperoleh 38 jenis fitoplankton dalam air tambak budidaya udang vaname superintensif di Kabupaten Barru. Plankton dalam berbagai bentuk seperti mikroalga, rotifer, dan kopepoda merupakan agen pembawa infeksi virus bintik putih atau white spot syndrome virus (WSSV) yang sangat potensial (Esparza-Lea et al., 2009). Ke-38 jenis fitoplankton ini ada yang diperoleh di dalam petakan tambak, inlet, outlet, dan IPAL, serta air laut sumber air untuk kegiatan budidaya. Fragillaria sp. merupakan jenis tertinggi (3.633 individu/mL) yang didapatkan, Thallasionema sp. (240 individu/mL) dan terendah adalah Skeletonema sp. (9 individu/mL). Hasil pengamatan diperoleh 11 jenis zooplankton. Jenis Brachionus sp. terdapat dalam jumlah tertinggi ( 273 individu/mL) dan yang terendah adalah Colurella sp. (8 individu/mL).

\section{KESIMPULAN}

Insidensi plankton yang terdeteksi mengalami infeksi positif WSSV terjadi pada bulan Januari, Oktober, dan November 2015 dengan prevalensi masing-masing $62,5 \%$ (empat dari tujuh sampel), $40 \%$

Tabel 3. Jenis dan kepadatan plankton yang diperoleh selama penelitian

Table 3. Plankton species and density found during the study period

\begin{tabular}{|c|c|c|c|c|c|}
\hline No. & Plankton & $\begin{array}{l}\text { Kepadatan }(\mathrm{sel} / \mathrm{mL}) \\
\text { Density }(\mathrm{cel} / \mathrm{mL})\end{array}$ & No. & Plankton & $\begin{array}{c}\text { Kepadatan (sel } / \mathrm{mL}) \\
\text { Density (cel } / \mathrm{mL})\end{array}$ \\
\hline & Fitoplankton & & & & \\
\hline 1 & Bacteriastrum sp. & 17 & 27 & Pleurosigma sp. & 39 \\
\hline 2 & Bacillaria sp. & 11 & 28 & Rhizosolenia sp. & 12 \\
\hline 3 & Bellerochea sp. & 59 & 29 & Rhabdonema sp. & 15 \\
\hline 4 & Biddulphia sp. & 16 & 30 & Skel etonema sp. & 9 \\
\hline 5 & Ceratium sp. & 88 & 31 & Stenoselamella sp. & 11 \\
\hline 6 & Chaetoceros sp. & 55 & 32 & Streptotheca sp. & 11 \\
\hline 7 & Chamaesiphon sp. & 11 & 33 & Stigmophora sp. & 11 \\
\hline 8 & Coscinodiscus sp. & 55 & 34 & Synechocystis sp. & 10 \\
\hline 9 & Climacodinium sp. & 11 & 35 & Thallasionema sp. & 240 \\
\hline 10 & Cyclotella sp. & 40 & 36 & Thallassiorira sp. & 27 \\
\hline 11 & Dactyliosolen sp. & 11 & 37 & Triceratium sp. & 12 \\
\hline 12 & Dynophisis sp. & 17 & 38 & Nitzschia sp. & 26 \\
\hline 13 & Eucampia sp. & 10 & & Zooplankton & \\
\hline 14 & Fragillaria sp. & 3,633 & 1 & Brachionus sp. & 273 \\
\hline 15 & Gleotrichia sp. & 51 & 2 & Colurella sp. & 8 \\
\hline 16 & Gymnodinium sp. & 32 & 3 & Favella sp. & 40 \\
\hline 17 & Gyrosigma sp. & 40 & 4 & Oithona sp. & 59 \\
\hline 18 & Guinardia sp. & 18 & 5 & Temora sp. & 83 \\
\hline 19 & Leptocylindricus sp. & 11 & 6 & Tintinnopsis sp. & 80 \\
\hline 20 & Lyngbia sp. & 10 & & Krustasea (Crustacea ) & (Organisme/mL) \\
\hline 21 & Melosira sp. & 37 & 1 & Acartia sp. & 66 \\
\hline 22 & Navicula sp. & 45 & 2 & Naupli copepoda & 82 \\
\hline 23 & Noctiluca sp. & 40 & 3 & Copepoda & 46 \\
\hline 24 & Oscillatoria sp. & 184 & 4 & Apocyclops sp. & 43 \\
\hline 25 & Prorocentrum sp. & 43 & & Cacing (Polychaeta) & (Organisme/mL) \\
\hline 26 & Protoperidinium sp. & 61 & 1 & Polychaeta & 34 \\
\hline
\end{tabular}


(empat dari 10 sampel), dan $66,67 \%$ (dua dari tiga sampel). Plankton dalam air sangat mudah menjadi vektor WSSV pada saat udang dalam petakan tambak terdeteksi mengalami infeksi WSSV.

\section{UCAPAN TERIMA KASIH}

Penelitian dibiayai dari APBN Balai Riset Perikanan Budidaya Air Payau dan Penyuluhan Perikanan (BRPBAP3) Maros, Kementerian Kelautan dan Perikanan Tahun 2015. Ucapan terima kasih disampaikan kepada pembudidaya udang vaname super-intensif yang ada di Kabupaten Barru yang telah memberikan izin pengambilan sampel selama penelitian. Demikian pula kepada rekan-rekan teknisi dan peneliti yang membantu dan mendukung pelaksanaan penelitian ini diucapkan terima kasih.

\section{DAFTAR ACUAN}

Oie (2013). IQ2000TM WSSV Intruction Manual (p. 25). Taiwan.

Botes, L. (2003). Phytoplankton identification catalogue. Globallast Monograph Series No. 7. Programme Coordination Unit Global Ballast Water Management Programme International Marine Organization. London, 77 pp.

Desrina, Sarjito, Haditomo, A.H.C., \& Chilmawati, D. (2012). The white spot syndrome virus (WSSV) load in Dendronereis spp. Journal of Coastal Develpopment, $15,270-275$.

Esparza-Lea, I.H.M., Escobedo-Bonilla, C.M., CasillasHernandez, R., Alvares-Ruiz, P., Portillo-Clark, G., Valerio-Garcia, R.C., Hernandez-Lopez, J., MendezLozano, J., Vibanco-Perez, N., \& Magallon-Barajas, F.J. (2009). Detection of white spot syndrome virus in filtered shrimp-farm water fractions and experimental evaluation of its infectivity in Penaeus (Litopenaeus) vannamei. Aquaculture, 292, 16-22. https://www. researchgate.net/publication/ 223949533

Liu, B., Yu, Z., Songa, X., \& Guan, Y. (2007). Studies on the transmission of WSSV (white spot syndrome virus) in juvenile Marsupenaeus japonicus via marine microalgae. Journal of Invertebrate Pathology, 95, 87-92.

Newell, G.E., \& Newell, R.C. (1977). Marine plankton a practical guide. $5^{\text {th }}$ edition. Hutchinson of London, $244 \mathrm{pp}$.

Nurhidayah, \& Tampangallo, B.R. (2013). Infeksi white spot syndrome virus (WSSV) pada pasca larva udang windu (Penaeus monodon) dengan media pemeliharaan yang berbeda. Seminar Nasional Tahunan X Hasil Penelitian Kelautan dan Perikanan. Jurusan Perikanan Fakultas Pertanian UGM. Jogjakarta, pPL-20, 1-5.

Otta, S.K., Shuba, G., Joseph, B., Anirban, C., \& Indrani K. (1999). Polymerase chain reaction (PCR) detection of white spot syndrome virus (WSSV) in cultured and wild crustaceans in India. Dis. Aquat. Org., 38, 67-70.

Rahman, M.M. (2007). Differences in virulence between white spot syndrome virus (WSSV) isolates and testing of some control strategies in WSSV infected shrimp. Thesis. Gent University. Belgium, 177 pp.

Soetrisno, C.K. (2004). Mensiasati penyakit WSSV di tambak udang. Aquacultura Indonesiana, 5(1), 1931.

Sànchez-Paz, A. (2010). White spot syndrome virus: An overview on an emergent concern. Vet. Res., p. 41-43.

Tampangallo, B.R., Muharijadi, A.M., \& Kadriah, I.A.K. (2016). Prevalensi WSSV dan vibriosis di sentra budidaya udang vaname super-intensif di Kabupaten Barru, Sulawesi Selatan. Laporan Teknis Akhir Kegiatan 2015. 26 hlm.

Tompo, A., \& Kurniawan, K. (2013). Distribusi penyakit WSSV pada areal pengembangan budidaya udang windu di Kabupaten Bulukumba. Prosiding Forum Inovasi Teknologi Akuakultur. hlm. 807-812.

Trobos. (2016). Mengukur kualitas dan kuantitas benur. Trobos Aqua. Majalah. Edisi Agustus 2016.

Xu, J., Han, F., \& Zhang, X. (2006). Silencing shrimp white spot syndrome virus (WSSV) genes by siRNA. Antivir. Res., 73, 126-131.

Yamaji, I. (1976). Illustration of marine plankton of Japan. Osaka, Japan: Hoikusha Publishing Co. Ltd., $369 \mathrm{pp}$.

Yan, D., Shuang-Lin, D., Huang, J., Xiao-Ming, Y., MinYi, F., \& Xiang-Yi, L. (2004). White spot syndrome virus (WSSV) detected by PCR in rotifers and rotifer resting eggs from shrimp pond sediments. Dis. Aquat. Org., 59, 69-73.

Zhang, J., Dong, S., Tian, X., Dong, Y., \& Liu, D. (2006). Studies on the rotifer (Brachionus urceus Linnaeus, 1758) as a vector in white spot syndrome virus (WSSV) transmission. Aquaculture, 261, 1181-1185.

Zhang, J., Shuang-Lin, D., Yun-Wei, D., Xiang-Li, T., \& Chun-Qiang, H. (2008). Bioassay evidence for the transmission of WSSV by the harpacticoid copepod Nitocra sp. Journal of Invertebrate Pathology, 97, 33-39. 